\title{
Prestasi Belajar Matakuliah Praktik Antara Semester Gasal dan Genap
}

\author{
Ricky Ronaldo*, Siti Nurrochmah \\ Universitas Negeri Malang, Jl. Semarang No. 5 Malang, Jawa Timur, Indonesia \\ *Penulis korespondensi, Surel: riky.junior26@gmail.com
}

Paper received: 24-5-2021; revised: 14-6-2021; accepted:21-6-2021

\begin{abstract}
Online learning in teaching and learning activities for practical courses is still a new thing to do. Therefore, the level of effectiveness of online learning in the movement/skills learning process deserves to be questioned. The purpose of this study was to find out and assess whether there was a significant difference in the learning achievement value of practical subjects between odd semester (before the pandemic) and even semester (before and during the Covid-19 pandemic) in students of the PJKR FIK Study Program, State University of Malang. This study uses a causal comparative design. Data analysis used the Anova technique, which first performed a prerequisite test for data normality. Different test forms of sample $t$ test are related. The results of data analysis showed that the coefficient of $t_{\text {count }}$ greater than or equal to table $\alpha$ is 0.05 . The conclusion of the research result is that there is a significant difference in the learning achievement score of the practical subject between odd semester (before the pandemic) and even semester (before and during the Covid-19 pandemic) students of the PJKR FIK Study Program, State University of Malang.
\end{abstract}

Keywords: learning achievement; practical courses; covid-19; odd and even semester; offline and online learning

\begin{abstract}
Abstrak
Pembelajaran daring dalam kegiatan belajar-mengajar mata kuliah praktik masih menjadi hal yang baru untuk dilakukan. Oleh karena itu tingkat keefektifitasan pembelajaran daring dalam proses pembelajaran gerak/keterampilan patut untuk dipertanyakan. Tujuan penelitian ini adalah mengetahui dan mengkaji ada tidaknya perbedaan yang signifikan nilai prestasi belajar mata kuliah praktik antara semester gasal (sebelum pandemi) dan semester genap (sebelum dan saat pandemi Covid-19) pada mahasiswa Prodi PJKR FIK Universitas Negeri Malang. Penelitian ini menggunakan rancangan causal comparative. Analisis data menggunakan teknik Anova yang terlebih dahulu dilakukan uji prasyarat normalitas data. Uji beda bentuk uji t sampel berhubungan. Hasil analisis data diperoleh hasil koefisien $t_{\text {nitum }}$ lebih besar atau sama dengan $t_{\text {tube }} \alpha$ yaitu 0,05 . Simpulan hasil penelitian adalah ada perbedaan yang signifikan nilai prestasi belajar mata kuliah praktik antara semester gasal (sebelum pandemi) dan semester genap (sebelum dan saat pandemi Covid-19) mahasiswa Prodi PJKR FIK Universitas Negeri Malang.
\end{abstract}

Kata kunci: prestasi belajar; mata kuliah praktik; covid-19; semester gasal dan genap; pembelajaran luring dan daring

\section{Pendahuluan}

Pendidikan adalah kegiatan pembelajaran untuk mendapatkan suatu pengetahuan/pengalaman baru. Menurut Undang-Undang Nomor 20 Sistem Pendidikan Nasional Tahun 2003, pendidikan adalah "penciptaan suasana belajar dan proses pembelajaran secara sadar dan terencana, agar peserta didik dapat secara aktif mengembangkan potensi dirinya, sehingga memiliki kekuatan spiritual keagamaan, kemandirian, dan kemandirian". kontrol, individualitas, kecerdasan, dan kemuliaan. Karakter. Dan keterampilan. Apa yang dia, masyarakat, negara, dan negara butuhkan." ( UU No.20 Tahun 
2003). Dunia pendidikan akan selalu berhubungan dengan belajar dan pembelajaran. Dengan kedua hal tersebut maka ilmu pengetahuan dapat berkembang.

Kegiatan belajar selalu ditandai dengan adanya interaksi antara pendidik dan peserta didik. Suyono dan Hariyanto (2011) Belajar adalah kegiatan atau proses memperoleh pengetahuan baru, meningkatkan keterampilan, memperbaiki perilaku, sikap, dan meningkatkan kepribadian. Yamin (2015) menjelaskan bahwa belajar adalah gerakan dan pergerakan yang edukatif untuk membuat para pembelajar memiliki pengalaman/keahlian baru yang baik dan bermakna. Oleh karena itu dapat disimpulkan bahwa belajar adalah proses untuk mendapatkan pengetahuan/keahlian baru, memperbaiki tingkah laku, sikap dan penampilan yang didapatkan dari pengalaman secara sadar, bisa dilakukan secara sengaja. Dikarenakan belajar adalah proses usaha, maka didalamnya terdapat tahapan yang harus dilewati agar bisa sampai kepada hasil belajar itu sendiri. Belajar merupakan aktivitas yang akan dilakukan secara terus-menerus atau tidak akan pernah berhenti selama manusia tersebut masih hidup.

Pembelajaran secara harfiah berarti suatu proses belajar. Arifin (2013) pembelajaran adalah suatu kegiatan belajar yang sistematis atau mempunyai sifat interaktif dan komunikatif antara pebelajar yaitu pendidik dengan peserta didik. Suprihatiningrum (2017) berpendapat bahwa pembelajaran adalah rangkaian kegiatan terencana yang dirancang untuk mendorong pembelajaran siswa dengan melibatkan informasi dan lingkungan. Oleh karena itu pembelajaran adalah suatu proses/kegiatan yang memerlukan adanya interaksi antara pebelajar yaitu pendidik dengan peserta didik yang sudah terencana, terlaksana dan dievaluasi secara sistematis untuk mencapai tujuan pembelajaran dan hasil belajar diperoleh dalam bentuk ingatan jangka panjang. Keberhasilan suatu pembelajaran dapat diukur dari perubahan tingkah laku yang terjadi pada pebelajar atau peserta didik/siswa. Pembelajaran dapat dikatakan suatu kegiatan belajar yang dilakukan berulang-ulang sehingga menyebabkan perubahan tingkah laku pada diri individu dan cenderung memiliki sifat tetap. Dalam pembelajaran terdapat beberapa komponen yaitu tujuan, sumber belajar, strategi pembelajaran, media pembelajaran, dan evaluasi pembelajaran.

Pendidikan dapat dilakukan di setiap jenjang pendidikan, termasuk pada tingkat perguruan tinggi. Budaya dan sistem pendidikan dalam perguruan tinggi berbeda dengan jenjang pendidikan sebelumnya. Salah satu perbedaannya yaitu mengenai sistem kredit semester (SKS) yang dapat membuat mahasiswa untuk memilih matakuliah yang ingin diambil atau mengambil kembali (retake) beberapa mata kuliah yang sebelumnya mendapatkan hasil tidak memuaskan. Pada tingkat perguruan tinggi hasil selama masa perkuliahan dituliskan dalam bentuk Kartu Hasil Studi (KHS), kartu hasil studi adalah hasil penilaian mahasiswa selama satu semester yang telah dijalani sesuai dengan matakuliah yang sudah diambil. Kartu hasil studi bisa dijadikan sebagai acuan mahasiswa untuk melihat tingkat prestasi belajarnya.

Saefuddin \& Berdiati (2016) hasil akhir dari kegiatan belajar dapat diindikasikan dengan prestasi atau hasil belajar. Rusman (2017) hasil belajar merupakan sejumlah pengalaman yang didapatkan pendidik sebagai hasil dari kegiatan belajar yang mencakup ranah pengetahuan/ kognitif, sikap/ afektif, dan psikomotorik. Susanto (2018) hasil belajar merupakan keahlian/ kemampuan yang didapatkan siswa dalam melakukan kegiatan belajar. Keahlian yang didapatkan itu berkaitan dengan pengetahuan, konsep, pengertian, dan pekerjaan/ kegiatan yang dapat dikerjakan oleh pebelajar. Terdapat beberapa faktor yang dapat mempengaruhi 
prestasi belajar. Rusman (2017) faktor tersebut yaitu, faktor internal dan faktor eksternal. Berikut penjelasannya: Pertama faktor internal, dibagi menjadi dua golongan yaitu, 1) faktor psikologis seperti minat, intelegensi/pengetahuan, bakat, motivasi, dan lain sebagainya. 2) faktor fisiologis seperti kondisi badan, kesehatan, kebugaran, cacat jasmani, kelelahan, dan lain sebagainya. Kedua faktor eksternal dibagi menjadi dua golongan yaitu, 1) faktor instrumental seperti sarana, fasilitas, guru/pendidik, dan kualitas pengajaran. 2) faktor lingkungan meliputi lingkungan sosial dan lingkungan fisik.

Prestasi belajar saat ini sedang mengalami perubahan dikarenakan dunia sedang dikejutkan dengan adanya sebuah virus yang mempunyai pengaruh besar dalam seluruh aspek kehidupan. Pada bulan Desember 2019 dan bulan Januari tahun 2020 dunia dikejutkan dengan kedatangan/munculnya suatu penyakit baru yang disebabkan oleh virus. Pada awal kemunculannya, virus tersebut dikenal dengan nama 2019 Novel Coronavirus atau disingkat dengan 2019-nCov (WHO, 2020). Virus ini resmi dinamakan dengan nama/istilah Covid-19 pada tanggal 11 Februari 2020 oleh WHO (WHO, 2020a). Menurut Gorbalenya \& Lin (Abdillah, 2020: 13) Covid-19 adalah penyakit menular, hampir mirip dengan flu yang disebabkan oleh Sindrom Pernafasan Akut Parah Coronavirus 2 (SARS-CoV-2).

Dampak negatif yang ditimbulkan karena adanya virus Covid-19 ini sangat terasa pada sektor kesehatan dan ekonomi yang pada akhirnya juga mempengaruhi sektor-sektor lain seperti pemerintahan, keamanan, politik, pendidikan, bahkan pola interaksi masyarakat ikut berubah. Kehidupan masyarakat Indonesia yang sebelumnya saling salam dan sapa, kini berubah menjadi pola interaksi baru yang dimana hampir semua interaksi dilakukan melalui sosial distancing, physical distancing dan melalui internet atau media sosial lainnya. Semua itu dilakukan untuk dapat mencegah/memutus penyebaran virus Covid-19 sesuai dengan arahan pemerintah dan WHO. Dalam dunia pendidikan, pemerintah melalui Kementerian Pendidikan dan Kebudayaan telah melarang semua jenjang pendidikan dari TK, SD, SMP, SMA, dan Perguruan Tinggi untuk melaksanakan pembelajaran secara konvensional (tatap muka) dan menginstruksikan untuk menyelenggarakan atau melakukan kegiatan perkuliahan/ pembelajaran secara daring daring sesuai dengan Surat Edaran dari Kemendikbud Dikti No. 2 tahun 2020 (Kemdikbud, 2020). Sebagai alternatif permasalahan pembelajaran ditengah pandemic, maka pembelajaran jarak jauh (daring) dipilih untuk memenuhi tuntutan pembelajaran. Kurtanto (2017) pembelajaran daring yaitu jenis pembelajaran yang dapat menggunakan bantuan internet untuk mempertemukan siswa dan pendidik dalam kegiatan pembelajaran.

Namun pada kenyataanya pembelajaran daring di seluruh jenjang pendidikan masih belum bisa berjalan dengan baik, menurut pengalaman pribadi dari peneliti yang sudah pernah mengalami pembelajaran secara daring. Masih banyak peserta didik yang pada saat proses pembelajaran daring itu menganggap remeh misalnya, dalam aspek afektif seperti bermain sendiri pada saat proses pembelajaran, tidur pada saat pembelajaran, dalam aspek perangkat pembelajaran seperti koneksi jaringan yang belum bisa stabil di daerah tertentu, keterbatasan smartphone, dan lain-lain. Pembelajaran daring juga belum bisa efektif pada beberapa mata pelajaran atau matakuliah khususnya mata pelajaran atau matakuliah yang memerlukan aktivitas gerak seperti mata pelajaran praktik. Kurangnya tingkat keefektifitasan pada pembelajaran daring akan dapat mempengaruhi hasil prestasi belajar peserta didik khususnya pada mata pelajaran atau matakuliah pendidikan jasmani, kesehatan dan rekreasi. 
Pembelajaran daring dalam kegiatan belajar-mengajar mata kuliah praktik masih menjadi hal yang baru untuk dilakukan. Oleh karena itu tingkat keefektifitasan pembelajaran daring dalam proses pembelajaran gerak/keterampilan patut untuk dipertanyakan. Peneliti berasumsi bahwa terdapat perbedaan yang signifikan hasil prestasi belajar pada matakuliah praktik antara semester gasal dan semester genap mahasiswa pada Fakultas Ilmu Keolahragaan, Universitas Negeri Malang. Berdasarkan latar belakang permasalahan yang telah dipaparkan diatas, maka peneliti tertarik untuk melakukan penelitian dengan judul "Perbedaan Hasil Prestasi Belajar Mata Kuliah Praktik Antara Semester Gasal dan Genap 2019/2020 Mahasiswa Th. 2018 Prodi PJKR-FIK-UM". Tujuan penelitian adalah mengetahui dan mengkaji ada atau tidaknya perbedaan yang signifikan nilai prestasi belajar mata kuliah praktik antara semester gasal (sebelum pandemi) dan semester genap (sebelum dan saat pandemic Covid-19) pada mahasiswa Prodi PJKR-FIK-UM.

\section{Metode}

Rancangan penelitian yang digunakan adalah bentuk deskriptif kuantitatif dengan pendekatan yang digunakan berupa metode dokumentasi. Penelitian ini termasuk jenis penelitian expost facto bentuk causal comparative. Instrumen penelitian yang digunakan adalah instrumen bentuk non tes berupa dokumentasi. Penelitian instrumen non tes digunakan untuk menjaring data terkait nilai yang tercantum pada KHS semester gasal dan semester genap pada mahasiswa angkatan 2018 Prodi PJKR-FIK-UM tahun akademik 2019/2020. Analisis data yang digunakan berupa uji normalitas bentuk kolmogorov-smirnov, homogenitas menggunakan uji $\mathrm{F}$, uji hipotesis menggunakan uji beda bentuk uji t sampel berhubungan.

Populasi yang akan diteliti adalah mahasiswa dari Prodi PJKR-FIK-UM angkatan 2018 yang mengikuti pembelajaran pada semester gasal dan genap tahun akademik 2019/2020 pada offering $\mathrm{C}$ berjumlah 39 mahasiswa. Pengambilan sampel menggunakan teknik purposive proportionate systematic random sampling dengan porsi $90 \%$ dari jumlah total populasi, sehingga sampel yang akan diteliti berjumlah 35 mahasiswa dari 39 mahasiswa.

\section{Hasil dan Pembahasan}

\subsection{Hasil}

Hasil analisis data yang dipaparkan pada bahasan ini meliputi: (1) hasil analisis uji prasyarat, yaitu uji normalitas menggunakan uji Kolmogorov-smirnov, (2) hasil uji hipotesis menggunakan uji T sampel berhubungan.

\subsubsection{Hasil Analisis Data Uji Normalitas}

Uji normalitas adalah untuk mengetahui apakah distribusi data semua variabel yang diteliti sesuai dengan distribusi normal. Uji normalitas data untuk setiap skor, digunakan teknik uji Kolmogorov -smirnov dengan menggunakan taraf signifikansi $\alpha=0,05$. Data yang diuji dikatakan normal apabila $D_{\text {nitung }}<D_{\text {Tabel }}$. Hasil analisis data disajikan pada tabel dibawah ini. Berdasarkan paparan data yang telah diuji, hasil analisis data pada variabel hasil prestasi belajar mata kuliah praktik semester gasal koefisien $D_{\text {hitung }}=0,1423$, dan hasil analisis data pada variabel hasil prestasi belajar mata kuliah praktik semester genap koefisien $D_{\text {numg }}=0,1039$, sedangkan $D_{\text {abel }} \alpha=0,05=0,224$. Oleh karena kedua variabel prestasi belajar mata kuliah praktik semester gasal (III) dan semester genap (IV) koefisien $D_{\text {hitung }}<D_{\text {tabel }} \alpha=0,05$, berarti 
hipotesis kerja $\left(\mathrm{H}_{1}\right)$ ditolak dan hipotesis nihil $\left(\mathrm{H}_{0}\right)$ diterima. Artinya dari analisis data uji normalitas yang telah diuji, distribusi data pada variabel hasil prestasi belajar mata kuliah praktik semester gasal (III) genap (IV) berdistribusi normal.

Hasil uji normalitas dengan menggunakan teknik Kolmogorov-smirnov, menunjukkan berdistribusi normal, berarti analisis data uji beda bentuk uji t sampel berhubungan dapat dilanjutkan. Berikut ini disajikan hasil analisis uji beda bentuk uji t terhadap variabel prestasi belajar mata kuliah praktik semester gasal dan semester genap tahun ajaran 2019/2020 sebagai berikut.

\subsubsection{Hasil Uji t Sampel Berhubungan}

Berikut disajikan hasil analisis uji beda bentuk uji t sampel berhubungan pada variabel hasil prestasi belajar matakuliah praktik semester gasal dan semester genap tahun akademik $2019 / 2020$.

Tabel 1. Penyajian Hasil Analisis Uji Beda Bentuk Uji t Variabel Hasil Prestasi Belajar Matakuliah Praktik Semester Gasal dan Semester Genap Tahun Akademik 2019/2020

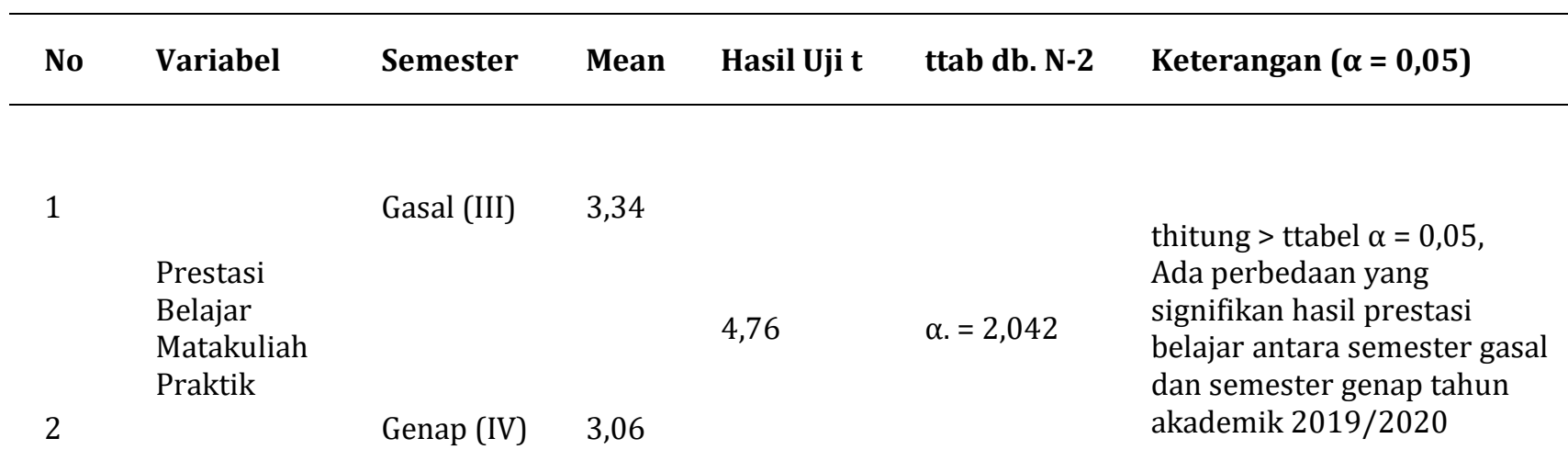

Berdasarkan hasil analisis data yang telah diuji pada tabel 1 tersebut di atas, maka hasil analisis data pada variabel prestasi belajar matakuliah praktik semester gasal dan semester genap tahun akademik 2019/2020 diperoleh koefisien $t_{\text {hitung }}=4,76$, dan $t_{\text {tabel }}=2,042$. Hasil uji menunjukan bahwa $t_{\text {hitung }}>t_{\text {tabel }}$, artinya hipotesis nihil $\left(\mathrm{H}_{0}\right)$ ditolak dan hipotesis kerja $\left(\mathrm{H}_{1}\right)$ diterima, artinya terdapat perbedaan yang signifikan hasil prestasi belajar matakuliah praktik antara semester gasal dan semester genap tahun akademik 2019/2020.

Pengujian hipotesis pada penelitian ini menggunakan uji beda bentuk uji t dengan tujuan untuk mengetahui perbedaaan rata-rata prestasi belajar matakuliah praktik pada pembelajaran luring semester gasal dan pembelajaran daring semester genap tahun akademik 2019/2020. Hasil analisis uji beda bentuk uji t yang telah disajikan pada tabel 3 diperoleh $t_{\text {hitung }}$ $=4,76$ dan $t_{\text {tabel }}=2,042$. Oleh karena $t_{\text {hitung }}>t_{\text {tabel }}$ pada taraf signifikasi 0,05 , berarti hipotesis nihil $\left(\mathrm{H}_{0}\right)$ yang menyatakan tidak ada perbedaan antara hasil prestasi belajar matakuliah praktik antara semester gasal dan semester genap ditolak, dan hipotesis kerja $\left(\mathrm{H}_{1}\right)$ yang menyatakan adanya perbedaan antara hasil belajar matakuliah praktik antara semester gasal dan semester genap diterima. Oleh karena itu dapat ditarik kesimpulan bahwa ada perbedaan 
yang signifikan antara hasil prestasi belajar matakuliah praktik antara semester gasal dan semester genap tahun akademik 2019/2020 pada mahasiswa offering C angkatan tahun 2018 PJKR-FIK-UM.

\subsection{Pembahasan}

Berdasarkan hasil paparan data yang sudah diuji pada tabel 3 diperoleh hasil koefisien $t_{\text {hitung }}$ sebesar 4,76 dengan koefisien $t_{\text {abee }}$ sebesar 2,042. Oleh karena koefisien $t_{\text {hitung }}>t_{\text {tabel, }}$ berarti dapat dikemukakan bahwa ada perbedaan yang signifikan prestasi belajar mata kuliah praktik antara semester gasal dan semester genap tahun akademik 2019/2020. Adanya perbedaan yang signifikan hasil prestasi belajar tersebut dapat dipengaruhi oleh beberapa faktor yaitu, faktor internal dan faktor eksternal (Rusman, 2017). Riyani (2015) menyatakan bahwa beberapa faktor yang dapat mempengaruhi prestasi belajar, adalah proses pembelajaran, metode, sumber, evaluasi, mahasiswa, lingkungan, kesehatan dan bakat. Wiarto (2015) menjelaskan dalam proses belajar motorik terdapat faktor-faktor yang dapat mempengaruhi hasil belajar, seperti faktor individu (potensi, bakat, kemauan, kemampuan), lingkungan (tempat seseorang melakukan proses pembelajaran), peralatan (sarana atau prasarana yang dapat menunjang proses pembelajaran, dan guru/pendidik. Keempat faktor tersebut saling berkaitan dalam rangka mewujudkan hasil proses belajar pembelajaran motorik yang optimal. Artinya jika salah satu faktor diabaikan maka proses pembelajaran gerak terhambat atau kurang lancar. Berarti hasil belajar yang diinginkan tidak akan tercapai.

Dalam penelitian ini mahasiswa menempuh proses pembelajaran pada semester gasal dan semester genap tahun akademik 2019/2020 yang artinya semester gasal merupakan semester 3 dan semester genap merupakan semester 4. Pada semester gasal proses pembelajaran atau kegiatan belajar mengajar menggunakan metode pembelajaran luring atau pembelajaran secara langsung atau tatap muka (face to face learning) yang dilaksanakan selama satu semester penuh atau selama empat bulan penuh. Pada semester genap proses pembelajaran atau kegiatan belajar-mengajar menggunakan dua metode pembelajaran, yaitu pembelajaran luring dan pembelajaran daring yang dilaksanakan dalam dua bulan pembelajaran luring dan dua bulan dilaksanakan secara daring. Pelaksanaan proses pembelajaran daring dilaksanakan dalam rangka untuk pencegahan perkembangan dan penyebaran Corona Virus Disease (Covid-19) di lingkungan satuan pendidikan sesuai dengan Surat Edaran dari Kemendikbud Dikti No. 3 Tahun 2020 (Kemdikbud, 2020b).

Anggrawan (2019) menyatakan bahwa pembelajaran tatap muka merupakan proses pembelajaran yang memerlukan kehadiran dosen pengajar dan mahasiswa untuk melakukan komunikasi atau interaksi secara verbal spontan pada lingkungan fisik permanen. Kehadiran pendidik/guru dan peserta didik/siswa dalam lingkungan belajar diperlukan supaya proses pembelajaran bias dilakukan, komunikasi antara pendidik dan peserta didik dilakukan secara bersama-sama, dalam waktu dan tempat yang sama (Wasis, 2018). Dalam pembelajaran mata kuliah praktik/pembelajaran gerak/pembelajaran keterampilan memerlukan koordinasi gerak yang dilakukan dalam kesadaran yang tinggi (Rusman, dkk., 2013). Artinya bahwa dalam belajar keterampilan motorik membutuhkan beberapa aspek utamanya adalah aspek koordinasi gerak yang merupakan salah satu aspek atau unsur kebugaran kinerja gerak. Oleh karena itu, agar seseorang mampu mengikuti pembelajaran keterampilan dengan baik dibutuhkan beberapa aspek/unsur kebugaran kinerja gerak seperti unsur kecepatan, kelincahan, kelentukan termasuk koordinasi. Hal tersebut didukung dengan pendapat Corbin, 
et al. (2009) berpendapat bahwa dalam unjuk kerja keterampilan gerak dibutuhkan komponen kinerja gerak seperti komponen keseimbangan, kelincahan, daya ledak otot, kecepatan dan koordinasi.

Isman (2016). Pembelajaran daring yaitu kegiatan pembelajaran/belajar yang menggunakan jaringan internet dalam pelaksanaanya. Maka karena itu kegiatan pembelajaran daring memerlukan bantuan dari perangkat-perangkat elektronik seperti smartphone, laptop, komputer, dan jaringan internet (Sadikin \& Hamidah, 2020). Pembelajaran daring mempunyai manfaat dalam pembelajaran gerak/keterampilan seperti pendidik dapat membuat blog atau website pribadi yang berisikan materi belajar, tugas dan hasil ulangan, sehingga jika nantinya terdapat kendala dalam proses pembelajaran, pendidik cukup memberikan instruksi untuk membuka $\mathrm{blog} /$ website-nya. Pendidik juga akan mudah untuk meninjau tugas peserta didik melalui website tersebut. Disamping itu pembelajaran daring juga memiliki kelemahan atau kekurangan seperti pembelajaran daring cenderung membuat orang menjadi pasif secara fisik, proses pembelajaran daring mempunyai sifat individual sehingga dapat mengurangi pembelajaran yang bersifat sosial, pembelajaran daring dapat membuat siswa cepat bosan belajar, dan pembelajaran daring dapat membuat siswa kurang memiliki sikap kritis karena tidak ada jaminan adanya kesesuaian informasi dengan materi yang disampaikan (Wiarto, 2016).

Berdasarkan hasil analisis data bahwa pada variabel hasil prestasi belajar semester gasal memperoleh nilai rata-rata sebesar 3,34, sedangkan pada variabel hasil prestasi belajar semester genap memperoleh nilai rata-rata sebesar 3,06. Sehingga dapat diketahui bahwasannya hasil prestasi belajar mata kuliah praktik pada semester gasal dengan menggunakan metode pembelajaran luring atau tatap muka lebih baik daripada hasil prestasi belajar mata kuliah praktik pada semester genap dengan menggunakan dua metode pembelajaran yaitu, pembelajaran luring dan daring. Hal ini sesuai dengan teori yang dikemukakan oleh (Uno \& Mohamad, 2015) dalam buku yang berjudul "Belajar dengan Pendekatan PAILKEM: Pembelajaran, aktif, inovatif, lingkungan, kreatif, efektif, menarik". Bahwasannya "penentuan atau ukuran dari pembelajaran yang efektif terletak pada hasilnya".

Mengapa proses pembelajaran luring lebih baik daripada pembelajaran daring? Hal ini dikarenakan pelaksanaan pembelajaran yang dilakukan secara luring memungkinkan pendidik untuk mengoptimalkan kemampuan siswa dalam belajar keterampilan/gerak dan menerapkan ciri-ciri pembelajaran. Disamping pelaksanaan pembelajaran daring dalam kegiatan belajar-mengajar juga tidak sepenuhnya efektif, hal ini didasari oleh pengalaman pribadi dari peneliti sendiri yang pernah mengikuti kegiatan perkuliahan pada tahun akademik 2019/2020. Selama kegiatan belajar-mengajar atau pembelajaran sedang berlangsung, banyak dari peserta didik yang tidak mengikuti instruksi pendidik, tidak menyalakan kamera sehingga pendidik kesulitan dalam mengontrol kelas sehingga kemungkinan peserta didik meninggalkan kegiatan belajar-mengajar semakin tinggi. Pembelajaran daring dalam kegiatan belajar-mengajar mata kuliah praktik masih menjadi hal yang baru untuk dilakukan. Karena pembelajaran daring bersifat satu arah dan dilakukan dengan jarak tertentu, sehingga interaksi langsung antara pendidik dan peserta didik menjadi tidak optimal. Hal ini menyebabkan proses pembelajaran mata kuliah praktik yang memerlukan aktivitas fisik menjadi sulit untuk dilaksanakan. Keterbatasan interaksi ini menjadi hal yang diwaspadai oleh pendidik saat proses pembelajaran berlangsung, dikarenakan dalam kegiatan aktivitas fisik 
risiko cedera sangat bisa terjadi, sehingga peran pendidik untuk mengawasi proses pembelajaran menjadi sangat penting.

Proses pembelajaran khusus pada matakuliah praktik selalu menuntut adanya unjuk kerja berupa aktivitas fisik dan interaksi langsung antara dosen dengan mahasiswa diperlukan guna menunjang tercapainya tujuan pembelajaran dari mata kuliah praktik tersebut. Melalui pembelajaran luring dalam pembelajaran praktik, pendidik akan mampu bertindak dalam proses pembelajaran secara optimal seperti menerapkan ciri-ciri pembelajaran. Wiarto (2015) berpendapat bahwa ciri-ciri pembelajaran sebagai berikut: (1) Pembelajaran yang dilakukan dan direncanakan secara sadar dan sistematis; (2) Pembelajaran bisa menumbuhkan perhatian dan motivasi siswa dalam proses belajar; (3) Bahan belajar dalam pembelajaran dapat menarik perhatian siswa dan menantang siswa; (4) Pembelajaran dilakukan dengan memanfaatkan alat bantu belajar yang sesuai, tepat dan menarik; (5) Pembelajaran bisa menciptakan suasana belajar yang menyenangkan dan aman bagi peserta didik; (6) Pembelajaran bisa membuat siswa menerima pelajaran, baik secara fisik maupun psikologi; (7) Pembelajaran dapat dilakukan secara sadar dan sengaja; (8) Pembelajaran menekankan keaktifan siswa.

Di dalam pembelajaran praktik atau gerak, mahasiswa mengendaki mampu menguasai materi keterampilan yang diberikan dosen/pendidik. Agar tujuan tersebut dapat dicapai maka prinsip belajar khususnya belajar gerak penting untuk diterapkan. Thobroni \& Mustofa (2013) menyatakan bahwa prinsip belajar sedapat mungkin menunjukkan kontinuitas atau berkesinambungan artinya keterampilan yang diberikan secara terus menerus banyak dilakukan, dan aktif yaitu siswa mampu merencanakan gerakan dan melakukan gerakan berulang-ulang. Disamping itu pula belajar merupakan suatu kebutuhan sehingga siswa harus aktif melakukan gerakan-gerakan tersebut, dan yang terpenting bahwa belajar merupakan bentuk pengalaman yaitu hasil interaksi antara mahasiswa dan lingkungan sekitar termasuk sumber belajar seperti pendidik atau teman sejawat yang menguasai gerakan. Dikatakan pula bahwa dalam belajar keterampilan motorik hasil yang diharapkan yaitu kemampuan yang dapat melakukan serangkaian gerak jasmani/fisik dan koordinasi gerak sehingga dapat terwujudnya otomatisasi gerak fisik untuk memperoleh gerak yang dikuasai. Hal tersebut didukung oleh pendapat Wiarto (2015) mengemukakan bahwa seseorang dapat diakui/dikatakan belajar apabila terjadi perubahan dalam dirinya sebagai akibat dari adanya suatu latihan atau pengalaman.

Keterbatasan, kekurangan dan kelemahan dari pembelajaran daring dalam belajar gerak dapat mempengaruhi prestasi belajar yang akan didapatkan mahasiswa. Rosyid, dkk., (2019: 09) mengemukakan bahwa prestasi belajar adalah suatu hasil yang dinyatakan dalam bentuk simbol, angka, huruf, dan kalimat yang diperoleh dari suatu proses belajar dan disertai oleh perubahan yang dicapai oleh seseorang (siswa). Sesuai dengan hukum belajar yang dikemukakan (Suyono \& Hariyanto, 2011) pada point Hukum persiapan menyatakan bahwa jika suatu respon dapat menghasilkan hasil yang memuaskan, maka hubungan antara stimulus dan respon akan semakin baik. Sebaliknya, jika suatu respon dapat menghasilkan hasil yang tidak memuaskan, maka hubungan antara stimulus dan respon akan semakin lemah. Artinya jika hasil belajar tidak memuaskan, maka semangat belajar juga akan berkurang yang nantinya akan berdampak pada hasil prestasi belajar. Oleh karena itu keefektifitasan pembelajaran daring khususnya pada matakuliah praktik menjadi hal yang perlu dikaji kembali oleh pendidik. 
Hasil penelitian ini selaras dengan penelitian yang dilakukan oleh (Nurdin \& Anhusadar, L., 2020) tentang "Efektivitas Pembelajaran Online Pendidik PAUD di Tengah Pandemi Covid 19" dan penelitian sejenis yang dilakukan oleh (Hadi, 2020) tentang "Persepsi Mahasiswa Terhadap Pembelajaran Daring Di Masa Pandemik Covid-19”. Bahwasannya pembelajaran daring masih belum efektif untuk membantu mahasiswa dalam belajar dan tidak semua orang tua mampu mendapatkan/memiliki sarana untuk pembelajaran daring.

\section{Simpulan}

Terdapat perbedaan yang signifikan hasil prestasi belajar antara semester gasal (sebelum pandemic) dengan semester genap (sebelum dan saat pandemic) tahun akademik 2019/2020. Hasil prestasi belajar mata kuliah praktik pada semester gasal dengan menggunakan metode pembelajaran luring atau tatap muka lebih baik daripada hasil prestasi belajar mata kuliah praktik pada semester genap dengan menggunakan dua metode pembelajaran yaitu, pembelajaran luring dan daring. Hal ini terlihat dari nilai rata-rata hasil prestasi belajar pada semester gasal $>$ nilai ratarata hasil prestasi belajar pada semester genap, yaitu 3,33 $>3,06$. Pembelajaran daring masih belum efektif untuk diterapkan pada pembelajaran yang dominan menggunakan aktivitas fisik pada mata kuliah praktik, dikarenakan keterbatasan interaksi yang terjadi pada saat proses pembelajaran sedang berlangsung/dilaksanakan. Resiko terjadinya cedera menjadi lebih tinggi sehingga peran dosen atau pendidik sangat penting dalam mengelola proses pembelajaran.

\section{Daftar Rujukan}

Abdillah, L. A. (2020). Stigma Terhadap Orang Positif COVID-19 (Vol. 2, pp. 11-24). Palembang: Universitas Bina Darma.

Anggrawan, A. (2019). Analisis Deskriptif Hasil Belajar Pembelajaran Tatap Muka dan Pembelajaran Online Menurut Gaya Belajar Mahasiswa. MATRIK: Jurnal Manajemen, Teknik Informatika Dan Rekayasa Komputer, 18(2), 339-346. https://doi.org/10.30812/matrik.v18i2.411

Arifin, Z. (2013). Evaluasi Pembelajaran. Bandung: PT Remaja Rosdakarya.

Corbin, C., Welk, G., Corbin, W., \& Welk, K. (2009). Concepts of Fitness and Wellness: A Comprehensive Lifestyle Approach. 8th Edition (8th ed.). New York: McGraw Hill.

Dwiyoko, W. D. (2018). Pembelajaran Berbasis Blended Learning. Depok: Rajawali Pers.

Hadi, L. (2020). Persepsi Mahasiswa Terhadap Pembelajaran Daring Di Masa Pandemik Covid-19 Student Perceptions of Online Learning During Covid-19 Pandemic. Jurnal Zarah, 8(2), 56-61.

Isman, M. (2016). Pembelajaran Moda dalam Jaringan (Moda Daring). The Progressive and Fun Education Seminar, 586-588. https://doi.org/http://hdl.handle.net/11617/7868

Kemdikbud. Surat Edaran Mendikbud Nomor 2 Tahun 2020 (2020).

Kemdikbud. Surat Edaran Mendikbud Nomor 3 Tahun 2020 (2020).

Kuntarto, E. (2017). Keefektifan Model Pembelajaran Daring Dalam Perkuliahan Bahasa Indonesia di Perguruan tinggi. Journal Indonesian Language Education and Literature, 3(1), 53-65. http://dx.doi.org/10.24235/ileal.v3i1.1820

Nurdin, N., \& Anhusadar, L. (2020). Efektivitas Pembelajaran Online Pendidik PAUD di Tengah Pandemi Covid 19. Jurnal Obsesi: Jurnal Pendidikan Anak Usia Dini, 5(1), 686-697. https://doi.org/10.31004/obsesi.v5i1.699

Pemerintah Republik Indonesia. (2003). Undang-undang Republik Indonesia nomor 20 tahun 2003 tentang sistem pendidikan nasional, 26.

Riyani, Y. (2015). Faktor-Faktor Ekstern Yang Mempengaruhi Prestasi Belajar Mahasiswa. Edunomic Jurnal Pendidikan Ekonomi, (2), 19-25. http://repository.polnep.ac.id/xmlui/handle/123456789/354

Rosyid, M. Z., Mustajab, \& Abdullah, A. R. (2019). Prestasi Belajar. (H. Sa'diyah, Ed.) (1st ed.). Malang: Literasi Nusantara. 
Rusman. (2017). Belajar \& Pembelajaran Berorientasi Standar Proses Pendidikan. (I. Fahmi \& Suwito, Eds.) (1st ed.). Jakarta: Kencana Predana Media Group.

Rusman, Riyana, C., \& Kurniawan, D. (2013). Pembelajaran Berbasis Teknologi Informasi dan Komunikasi: Mengembangkan Profesionalitas Guru (3rd ed.). Jakarta: PT Rajagrafindo Persada.

Sadikin, A., \& Hamidah, A. (2020). Pembelajaran Daring di Tengah Wabah Covid-19. Biodik: Jurnal Ilmiah Pendidikan Biologi, 6(2), 214-224. https://doi.org/10.17509/t.v6i2.20887

Saefuddin, A., \& Berdiati, I. (2016). Pembelajaran Efektif. (A. Kamsyach, Ed.) (3rd ed.). Bandung: PT Remaja Rosdakarya.

Suprihatiningrum, J. (2017). Strategi Pembelajaran Teori dan Aplikasi. (R. K. Ratri, Ed.) (2nd ed.). Yogyakarta: Ar-Ruzz Media.

Susanto, P. (2018). Belajar Tuntas, Filosofi, Konsep, dan Implementasi. (L. M. Ali, R. D. Aningtyas, \& N. Syamsiyah, Eds.) (1st ed.). Jakarta: PT Bumi Aksara.

Suyono, \& Hariyanto. (2011). Belajar dan Pembelajaran. (A. S. Wardan, Ed.) (2nd ed.). Bandung: PT Remaja Rosdakarya.

Thobroni, M., \& Mustofa, A. (2013). Belajar dan Pembelajaran: Pengembangan Wacana dan Praktik Pembelajaran dalam Pembangunan Nasional. (M. Sandra, Ed.) (2nd ed.). Yogyakarta: Ar-Ruzz Media.

Uno, H. B., \& Mohamad, N. (2015). Belajar dengan Pendekatan PAILKEM: Pembelajaran, Aktif, Inovatif, Lingkungan, Kreatif, Efektif, Menarik. (D. Ispurwanti, Ed.) (6th ed.). Jakarta: PT Bumi Aksara.

WHO. (2020a). Naming the coronavirus disease (COVID-19) and the virus that causes it.

WHO. (2020b). Q\&A on coronaviruses (COVID-19).

Wiarto, G. (2015). Inovasi Pembelajaran Dalam Pendidikan Jasmani (1st ed.). Yogyakarta: Laksitas.

Wiarto, G. (2016). Media Pembelajaran Dalam Pendidikan Jasmani (1st ed.). Yogyakarta: Laksitas.

Yamin, M. (2015). Teori dan Metode Pembelajaran. (H. Salmi, Ed.). Malang: Madani. 